\title{
Energy policies of the USA in the first decade of 21st century
}

\author{
Hakan Çora ${ }^{1, *}$ and Elnur Hasan Mikail ${ }^{2}$ \\ ${ }^{1}$ Istanbul Okan University, Istanbul, Turkey \\ ${ }^{2}$ Kafkas University, Kars, Turkey
}

\begin{abstract}
At the end of the 20th century, the USA's environmental and energy policies were based on its international influence and domestic lobby groups. However, by the beginning of the new millennium, this country on the did not believe in its undisputed global leadership position in the unipolar world and changed its policies in line with global domination under the new conservatives' influence. After 2001, the events allowed the neoconservatives to apply the philosophies theoretically formed and developed since 1930 in practice. The policies, including energy, environment and other strategic issues, of the government administration, which was determined with neoconservative motives, faced a great reaction and the domestic support began to decline. The neoconservatives faced that their policies that were inconsistent with the facts and resulted in a great disappointment in the U.S. public opinion.
\end{abstract}

\section{Introduction}

The presidential election held in 2000 has been the most talked-about subject in the history of the United States, which has been determined in the longest time and has been submitted to the Supreme Court. Republican candidate George W. Bush won the Presidency because of the large number of delegates, while he received fewer votes than his rival, Democratic Party's Al Gore. Due to the repeatedly counted votes in Florida in favor of Bush with a slight margin, it became clear that Bush was the winner with four votes to five out of nine, while Al Gore carried the result to the High Court. Some intellectuals and opposition groups described it as "the coup of neoconservatives" [1].

The George Bush administration has brought back the neoconservatives, who were active in the Reagan administration, back to Washington. The neoconservatives, who attach vital importance to the U.S. military power and believe that it should be unrivalled, gradually took part in the Bush administration's defence and foreign policy levels. Deputy Secretary of Defence Paul Wolfowitz, Undersecretary of Defence Policy Dougles Feith, National Security Council's Elliot Abrams, Vice-President Cheney's Chief of Staff Lewis Libby, Pentagon Defence Policy Board Chairman Richard Perle was some of the main neoconservatives. They set George W. Bush's agenda [2].

\footnotetext{
* Corresponding author: corahakan@gmail.com
} 
Michael Mann quotes Bush's thoughts on this team in his book: "In September 2000, Paul Wolfowitz held senior positions at the White House and the Department of Defence at least five other people along with John Bolton. The conservative think tank organization prepared the Rebuilding America's Defences project for the New American Century Project. The project was generally based on the anti-ballistic missile treaty, the armament against Iran, Iraq, and North Korea, and a $24 \%$ increase in military spending. They also added that the world needs American leadership, not the United Nations leadership. John Bolton is the current Under Secretary of Arms Control and International Affairs and is a prominent hawk in the United States " [3].

John Bolton is one of the strictest neoconservatives who has never been out of line since the Ronald Reagan era. At the height of the Vietnam War, he avoided enlistment by joining the National Guard responsible for the country's internal security, saying that he did so because he felt the war was lost because of the liberals who prevented America from taking the necessary steps to win. "I would not waste time on a futile effort." expressed Bolton. Besides, Bolton later expressed his regret on this issue: "It was one thing to die for your country, but it seemed absurd to me to die to gain territory that the anti-war forces in Congress would return to the enemy. Looking back, I am not too proud of this calculation." [4].

In this perspective, it is essential to understand John Bolton, who witnessed and ruled a long political period. He was one of the administration's dominant names when he was the Undersecretary of Arms Control. When he was appointed as the ambassador to the U.N., he was accused of undermining Secretary of State Colin Powell, two intelligence analysts, and directors who disagreed with him in the Bush administration. Bolton was also among those who created the perception that Saddam Hussein, which later turned out to be a lie, possessed mass destruction weapons [4].

Neither President Bush, Vice President Dick Cheney, nor Defence Secretary Rumsfeld was neoconservatives, and neither had been viewed as neoconservative until the day the U.S. invaded Iraq in 2003. However, Bush had neoconservative foundations. Douglas Feith brought names such as Eliott Abrams and Paul Wolfowitz to high positions. During his Presidency, he adopted neoconservative rhetoric. However, such names have been welcomed within the administration by genuine realists such as National Security Advisor Condoleezza Rice and Secretary of State Colin Powell [5].

While the Bush administration has not radically changed its predecessor Bill Clinton's policies since the day, it took office, and the September 11 attacks have been the turning point of this trend. In the last period, the administration was brutally criticized by many neoconservatives, and the policies followed were described as a national shame by the leaders of the movement, such as Kagan and Kristol. Therefore, we will discuss the American foreign policy shaped under the influence of neoconservative figures due to the September 11 attacks in this section [2].

\section{September 2001 attacks and the fight against terrorism}

September 11, 2001, marks a new beginning for international relations both for America and the rest of the world when nothing can be the same as before. On the morning of September 11, 2001, nearly three thousand people died due to the attack by al-Qaeda terrorists by hijacking passenger planes at the World Trade Center in New York and the U.S. Department of Defence in Washington, Pentagon. The astounding attack on its homeland at a time when the absolute victor of the cold war and benevolent hegemony power of the world never expected brought many changes with it [2].

On September 11, 2001, two of the four passenger planes hijacked by terrorists crashed into the twin towers in New York, while one targeted the Pentagon in Washington DC and 
another crashed in the Pennsylvania countryside due to the fight between the hijackers and passengers. Due to the fire caused by the impact, the twin towers were fallen, and thousands of civilians collapsed and lost their lives. As the U.S. was faced with such a massive and planned attack on its soil, it changed the security perceptions. Because the Al Qaeda terrorist organization, which is blamed for the attacks, was protected by the Taliban regime in Afghanistan, Osama Bin Laden and other terrorists were asked to be delivered to the USA, and the terrorist camps were destroyed. However, the Taliban regime claimed no definitive evidence that the attack was carried out by Al Qaeda [6]. In his address to the nation four days after the attacks, President Bush said: "We are at war, there is a war waged against America by terrorists, and we will respond to this war. We will find out who did it, and we will bring them to justice by removing them from their hiding places" [6].

In his speech to Congress on September 20, 2001, he underlined that all nations worldwide should decide, and that the USA will accept anyone who does not cooperate with the USA to fight against terrorism as being with terrorists. Besides, he expressed that every nation that allows terrorism and terrorists to shelter and will continue to support them in the next term will be perceived as an enemy for the USA and gave the message to all countries that they should make a choice [7]. Neo-conservatives perceived the September 11 attacks as a new Pearl Harbor. The neoconservatives, who found grounds to put their ideas into action, engaged in propaganda that the United States should fight against international terrorism, terrorists, and those who helped them by using national and international media channels and mobilizing non-governmental organizations [8]. For neoconservatives, radical Islamic terror has now replaced the communist threat of the Cold War. While accelerating the process leading to the Iraq War by addressing this new enemy a lot in journals such as The Public Interest, The National Interest, and Commentary Magazine, which are their publications, the U.S. public has played a significant role in creating a perception to legitimize this war.

In an article published in The Heritage Foundation in 2002, John Bolton, one of the symbolic figures of neoconservatives, regarding the 9/11 attacks:

"The September 11 attacks reinforced with great clarity the need to be determined in the face of threats to our security. The international security environment has changed, and our greatest threat comes from transnational terrorist cells that will attack using weapons of mass destruction, not from the spectre of nuclear war between the two superpowers, as it did during the Cold War. Every country, not just the United States, has to reassess its security situation and decide where it stands in the fight against terrorism." [4].

The new conservatives, who had waited a long time to put their plans into action, had a great opportunity due to the September 11 attacks. The U.S. administration, which had the perception that the stability of the political and economic global order was based on the hegemonic power of the USA before September 11, 2001, clearly showed that the perception on this issue had changed radically in President Bush's speech at the United States Military Academy on June 1, 2002. "The war on terror cannot be won by the defence. We must take the battlefield into the enemy's territory, disrupt their plans, and neutralize the threats that may arise from it before they appear. In today's world, the only way to security is through action ... " [4].

Bush went beyond the rhetoric of war against terrorism that he had used until the day he gave this speech and pointed to a neo-imperial understanding of security based on absolute control instead of a benevolent hegemon. Accordingly, the United States would no longer pursue the great states' cooperation to ensure common security and prevent all possible rivals that could challenge the U.S. military power. In doing so, it will not rely on traditional realist policy methods (such as containment, deterrence) or the recently fashionable neo-liberal policy methods (strategic partnership, globalization, multilateral 
cooperation, etc.), but rather neo-conservative policies that emphasize pre-acquisition strategy [9].

\section{The reflections of the september 11 attacks on domestic policy}

While the September 11 attacks created a shock effect for the American administration and the people, it also brought along discussions about the security weakness. As the U.S. administration and the American people faced that their country's security was not as strong as they thought, the administration implemented a series of reforms to close the security gaps. The administrations and circles ignored the complaints that the legal arrangements made per the reform restricted the American people's rights and freedoms under neoconservatives' influence. The influence of the neoconservatives to Strauss caused them to adopt a strong interventionist and authoritarian state understanding in American foreign and domestic politics [10].

Following September 11, we can discuss the U.S. administration's reforms regarding internal security under three main headings: the establishment of Homeland Security, the PATRIOT Act, and the 2004 Intelligence Reform and Terrorism Prevention Act. The main reason for implementing such reforms was the destruction of terrorist groups, the acceleration of detecting members of terrorist organizations, and bringing them to court. Besides, preventing the repetition of mistakes made before and during September 11 is also effective in realizing the reforms mentioned above [2]. To briefly touch on these reforms:

- Homeland Security Organization.

Although the Homeland Security Organization was established by law in 2002, it started its operations in 2003 due to the discussions because it restricts fundamental rights and freedoms. Bringing twenty-two institutions under one roof is one of the largest federal agencies in the United States. The institution has three primary missions: to prevent a new terrorist attack within the borders of the USA and to create a safer environment for citizens, closing the country to terrorist attacks, to reduce the damage done and to provide strategic support to other institutions to eliminate the effects of such an attack [11].

- PATRIOT Law.

The law, which came into force as little as a month after the September 11 attacks, was enacted for laws on terror and terrorism, as well as binding provisions in areas such as money laundering, wiretapping, and increasing the powers of search permits. The most important aspect of the PATRIOT Act is that it grants federal and local powers broad powers to listen and follow people who are thought to be members of a terrorist organization. The PATRIOT Law's primary objectives were to increase the federal government's intelligence-sharing capacity, harden the anti-terrorism laws, and eliminate the obstacles in front of institutions investigating terrorist crimes [11].

- Intelligence reform and terrorism prevention law.

It was created with the recommendations of the 9/11 Commission to gather fifteen intelligence organizations under one roof. With this law, a new National Intelligence Directorate that can organize all intelligence agencies was established. Thus, all intelligence information will be collected on a single roof, and coordination between intelligence organizations will be achieved [11].

\section{Bush doctrine}

There are doctrines in the U.S. political tradition named after each President and include all kinds of policies the President has set. The priority decisions in forming the foreign policy 
belong to the President, and a policy is followed per his views. The Presidents' doctrines are considered as a fundamental element in foreign policy [2].

While the attacks of September 11, which had a revolutionary effect in the strategic view of the Bush administration and neoconservatives, and the United States National Security Strategy Document signed by President Bush in 2002, set the general framework of the Bush doctrine, it was also an explicit declaration that a foreign policy under the influence of neoconservatives would be implemented [10].

In the White House Section of the National Security Strategy Document published in September 2002, there are essential data regarding the policies to be followed by the USA in the new term. It is possible to list the most striking lines of the section bearing President Bush's signature. "Terrorists are organized to penetrate open societies and direct modern technologies against us. To defeat this threat, it is necessary to use strong efforts to cut down every middleman-military force in our arsenal, a better homeland defence, law enforcement, intelligence, and terrorist financing [12].

War against terrorists on a global scale is a global undertaking for an indefinite period. America will assist/support nations that need our help in the war against terrorism.

The United States and countries that cooperate with us should not allow terrorists to develop new home bases. Together we will try to contain them in their shelters at every opportunity. The gravest danger facing our nation lies at the intersection of radicalism and technology. Our enemies have openly declared their pursuit of weapons of mass destruction, and the evidence shows that they are doing so with determination. The United States will not allow these efforts to succeed [12].

America will act against such emerging threats before they are fully formed. We cannot defend America and our friends, hoping for the best. That is why we must be prepared to defeat our enemies' plans by using the best intelligence and moving forward with determination. History will vigorously judge those who see this coming danger but fail to act. In the new world, we are entering, the only road to peace and security is the path of action.... And America will respond by conquering states/nations that agree/compromise with terrorism, including those who protect terrorists, because the allies of terrorism are the enemies of civilization." [12]

This document, also known as the Bush Doctrine, underlined that U.S. foreign policy would be made more aggressive due to security concerns. The U.S. foreign policy, which was built on deterrence and containment policies during the Cold War, has taken on a new form per the pre-emptive and pre-emptive war strategy with the Bush Doctrine. Preemptive war strategy involves eliminating a threat that is perceived as severe before allowing it to materialize. Accordingly, the United States claimed to have the right to conduct military intervention against any state that supports international terrorism, is thought to harbour terrorists, or possess nuclear, biological, or chemical weapons of mass destruction [13].

Former U.S. Secretary of State Henry Kissinger also states that the traditional concept of nation-state sovereignty of the Westphalian era has now changed, terrorists have disappeared without a trace by using modern technology, therefore states that train and host terrorists cannot hide behind the classical understanding of sovereignty and therefore the existence of a severe terrorist threat originating from the territory of a sovereign state and adds that it is a right stemming from the nature of the problem to be able to intervene against this state, including military action. While the legitimacy of the concepts of proactive and pre-emptive war following the publication of the Strategy Document caused much debate in the following periods, it was used by the U.S. administration as the legitimate justification of the military operations of the USA in Afghanistan and Iraq at every opportunity [14]. 
The National Security Strategy Document emphasized that the supremacy of the U.S. military power should always be maintained, as well as preventive military operations against terrorists and enemy states that are considered to pose a threat to the security of the USA, democracy, and human rights all over the world, especially the Middle East and Islamic world, should be widespread. Because anti-democratic and totalitarian regimes in the Middle East and Islamic geography caused global terror, the Great Middle East Project's idea was put forward to transform such regimes. This project was created based on neoconservative references. As the internal structures of regimes are also crucial for neoconservatives, there is a parallel between the regime and the society, or the regime and culture. Regime change will bring about the change of citizens, culture, and civilization. Believing that the nature of the regime affects the extroverted behavior of the society they are in, neoconservatives thought that they could only achieve this through regime change, to transform the society against possible threats from the Middle East and the Islamic world [15].

\section{The Great middle East project}

There are theses of American political scientists Francis Fukuyama and Samuel Huntington in the background of the Great Middle East Project's idea, one of the most speculative chapters of the last century. While the Great Middle East Project was listed for the first time by President Bush in the American Enterprise Institute, the bastion of neoconservatives, the reasons for intervention in Iraq were listed, the Saddam regime's demolition and the possible democratic regime to be established in Baghdad. It was brought to the agenda with the expectation that it would create a domino effect [16]. At the G-8 Summit in June 2004, it was named "Broader Middle East and North Africa Initiative". This initiative mainly aims to eliminate the region's instability, struggle with countries that support terrorism, support economic and political developments per the free-market model, and solve the Palestine-Israel problem. It was thought that by bringing freedom and democracy to the Middle East, poverty would come to an end, and the resources fed by terrorism would be drained. Military methods could be used if necessary for these purposes, depending on the belief that economic, social, and political problems fuel fundamentalism and radicalism in the region [17].

i. The democratic character of the regimes and administrations in the countries of the region and their integration with the international system,

ii. The elimination of threats arising from this geography for the global system,

iii. Providing economic development in the countries of the region, reducing dependence on energy incomes, increasing the welfare of the people,

iv. Ensuring the security of the region's energy reserves, production areas, and transportation routes, maintaining energy supply and energy price stability,

v. Development of the Middle East Trade Initiative.

Per these objectives, Turkey serves as a model state as most of the population is Muslim and a secular democratic country. In the following period, the project was implemented to eliminate threats through democratization, and interventions in Afghanistan and Iraq were conducted by the U.S. administration, respectively [17].

\section{Conclusion}

At the end of the 20th century, the USA did not believe in its undisputed global leadership position in the unipolar world and changed its policies in line with global domination under the New Conservatives' influence during the W. Bush term. The attack of the Twin Towers 
on September 11, 2001, laid the groundwork for this goal, allowing the neoconservatives to apply the philosophies theoretically formed and developed since 1930 in practice [18].

The Afghanistan and Iraq Wars after the Greater Middle East project has been a manifestation of neo-conservative thought to the press. The idea that democracy can be imposed on countries ruled by a dictatorship and that force can be used when necessary, the USA bases this on moral grounds, and the ignoring of the international community and institutions proves this. Perry Anderson, an expert on history and sociology, argues that the rise of neoconservatives after the Cold War brought their end. As the USSR's sudden collapse brought a sense of self-confidence, the USA could shape the global order alone. While this uncontrolled rise is advantageous for neoconservatives, the feeling of excessive self-esteem that developed soon led to an illusion in the Iraq War, as Fukayama points out. After the Cold War, Fukuyama, a former neoconservative, stated that the neoconservatives misinterpreted the U.S.'s power [18].

The USA's reputation, especially shaken by the Iraq War, caused the stars of different powers such as Russia and China to shine in the world. The rise in oil prices due to Iraq's invasion brought along the increase in Russian State power. In the post-Cold War period, the USA had a positive image in the world public opinion and states as the winner of the war and the only superpower. It has been instrumental in reinforcing this positive perception, especially in the humanitarian interventions it has undertaken under the United Nations and NATO auspices, with the international community's approval and international law. In this period, the U.S. seems to be a more "benevolent" hegemonic power. Due to the September 11 attacks against this benevolent hegemony, this positive perception continued to be preserved with the support and sympathy displayed in the world public opinion against the USA. As a sign of this, the USA was not left alone in the intervention in Afghanistan. However, as the USA did not settle with Afghanistan regarding military intervention and carried the conflict to the Iraqi field and while doing so, showing an attitude that did not care about international law and the international community caused this positive perception to be broken. In their analysis article published in the National Interest in 2008, Andrew Kohut and Richard Wike assessed the USA's image in the Islamic world after the Iraq War, accordingly. In their analysis, the authors expressed that antiAmericanism strengthened in the Arab world in the Middle East and spread to different parts of the Islamic world, such as Turkey and Indonesia. They noted the fight against terrorism, Iraq, U.S. support for Israel, and other vital features of U.S. foreign policy as reasons for the emergence of U.S. hostility in Asia and elsewhere in the Middle East [19].

The foreign policy of the Bush administration, which was determined with neoconservative motives, faced a great reaction, especially due to the Iraq War, and after the re-election of President Bush in 2004, support for the Bush administration began to decline. The neoconservatives faced that their policies that were inconsistent with the facts and resulted in a great disappointment in the U.S. public opinion started to lose their place in the Bush administration one by one with the declining support for Bush in the U.S. public opinion and the loss of Republicans against Democrats in the 2006 midterm elections. During the process leading up to the 2008 Presidential elections, the crisis in Iraq deepened day by day and turned into an inextricable state, and the American image that was upset brought the end of the Republican, i.e. Bush, administration.

\section{References}

1. M. Yanardağ, Neo-Cons America's Black Book (Chiviyazilari, Istanbul, 2004)

2. M. Zuckoff, M. Fall and rise: The story of 9/11 (HarperCollins, Newyork, 2019) 
3. J. Mann, Rise of the Vulcans: The History of Bush's War Cabinet (Penguin Books, Newyork, 2004)

4. J. Bolton, Beyond The Axis of Evil: Additional Threats from Weapons of Mass Destruction (Grove Press, Newyork, 2004)

5. Z. Larwood, The neoconservative theory of international politics (Masters Thesis, American University in Cairo, 2018)

6. H. Önal, The Dilemmas of USA's Afghanistan Policy: A Regional Analysis, Journal of International Law and Politics 6, 23 (2010)

7. F. Tademir, The Path to International Anarchy: Preventive Legitimate Defense in Terms of International Law, International Journal of Law and Politics 2, 5 (2006)

8. S. Örnek, September 11 Events and Afganistan Operations, Yalova University Law Journal 12, 1 (2012)

9. M. Aydin, The Past, The Present And The Future Of Terrorsism: A Political Realist Assessment, Süleyman Demirel University Journal 19,3 (2014)

10. Ç. Özen, I. Irem, Straussian Foundations of New Conservative American Foreign Policy (Odak, 2006)

11. S. Özeren, H. Cinoglu, Terrorism and the United States: Evaluation of anti-terrorism policies before and after September 11 (USAK, Istanbul 2006)

12. E. Kandemir, The Alliance Discourses in "the White House" Part of the National Security Documents Released in the Terms of USA Presidents G.W. Bush and B. Obama and S. Walt's Alliance Theory, The Journal of Defense Sciences 10, 2 (2011)

13. S. Dönmez, Preemptive and Preventive Attack Concepts within the Scope of Using Force, IV. IBANESS Congress Series - Russe / Bulgaria (2017)

14. H. Kissinger, Preemption and The End Of Westphalia (New Perspectives Quarterly, 2002)

15. G. Ermağan, The Foreign Policy of the USA after the Cold War, The Period of Obama and AK Party, Electronic Political Sciences Research Journal 3, 2 (2012)

16. Ö. Kurtbağ, American New Right and Foreign Policy (USAK, Istanbul 2010)

17. Z. Brzezinski, B . Scowcroft, America and the World: Conversations on the Future of American Foreign Policy (Basic Books, Newyork, 2009)

18. P. Anderson, American Foreign Policy and Its Thinkers (Verso, Newyork 2017)

19. A. Kohut, B. Strokes, America Against the World (St Martins Grifin, USA, 2007) 